\title{
Cloud condensation nuclei activity of fresh primary and aged biomass burning aerosol
}

\author{
G. J. Engelhart ${ }^{1}$, C. J. Hennigan ${ }^{1}$, M. A. Miracolo ${ }^{1}$, A. L. Robinson ${ }^{1}$, and S. N. Pandis ${ }^{1,2,3}$ \\ ${ }^{1}$ Center for Atmospheric Particle Studies, Carnegie Mellon University, Pennsylvania, 15217, Pittsburgh, USA \\ ${ }^{2}$ Department of Chemical Engineering, University of Patras, Patra, Greece \\ ${ }^{3}$ Institute of Chemical Engineering Sciences, Foundation of Research \& Technology, Patra, Greece
}

Correspondence to: S. N. Pandis (spyros@chemeng.upatras.gr)

Received: 20 February 2012 - Published in Atmos. Chem. Phys. Discuss.: 16 March 2012

Revised: 25 July 2012 - Accepted: 25 July 2012 - Published: 13 August 2012

\begin{abstract}
We quantify the hygroscopic properties of particles freshly emitted from biomass burning and after several hours of photochemical aging in a smog chamber. Values of the hygroscopicity parameter, $\kappa$, were calculated from cloud condensation nuclei $(\mathrm{CCN})$ measurements of emissions from combustion of 12 biomass fuels commonly burned in North American wildfires. Prior to photochemical aging, the $\kappa$ of the fresh primary aerosol varied widely, between 0.06 (weakly hygroscopic) and 0.6 (highly hygroscopic). The hygroscopicity of the primary aerosol was positively correlated with the inorganic mass fraction of the particles. Photochemical processing reduced the range of $\kappa$ values to between 0.08 and 0.3 . The changes in $\kappa$ were driven by the photochemical production of secondary organic aerosol (SOA). SOA also contributed to growth of particles formed during nucleation events. Analysis of the nucleation mode particles enabled the first direct quantification of the hygroscopicity parameter $\kappa$ for biomass burning SOA, which was on average 0.11 , similar to values observed for biogenic SOA. Although initial CCN activity of biomass burning aerosol emissions are highly variable, after a few hours of photochemical processing $\kappa$ converges to a value of $0.2 \pm 0.1$. Therefore, photochemical aging reduces the variability of biomass burning $\mathrm{CCN} \kappa$, which should simplify analysis of the potential effects of biomass burning aerosol on climate.
\end{abstract}

\section{Introduction}

Biomass burning is a major source of aerosol emissions globally (Andreae et al., 2004; Crutzen and Andreae, 1990). These aerosols have the potential to activate to form cloud droplets and therefore impact cloud properties and climate. Biomass burning also emits a large amount of water vapor and has the potential to form pyro-cumulus clouds with relatively high supersaturation conditions (Reutter et al., 2009). Atmospheric modeling has shown that biomass burning is an important global source of CCN (Pierce et al., 2007; Spracklen et al., 2011). Given the potential importance of $\mathrm{CCN}$ from biomass burning it is critical to understand their hygroscopicity and how it evolves in the atmosphere.

Early work demonstrated that in high supersaturation ( $>0.5 \%$ ) conditions biomass burning aerosols can be effective CCN (Warner and Twomey, 1967; Hobbs and Radke, 1969; Eagan et al., 1974). More recent research has shown that some biomass burning aerosols can activate at supersaturations as low as $0.05 \%$ (Rogers et al., 1991), which would be more typical of a stratiform cloud.

Laboratory experiments have been performed to investigate the CCN activity of primary biomass burning aerosols emitted during the burning of a wide range of fuels (Petters et al., 2009; Dusek et al., 2005; Novakov and Corrigan, 1996). Petters et al. (2009) observed highly variable CCN activity of primary aerosol emitted from the combustion of over 20 vegetation types. This variability creates a challenge for regional and global modeling of $\mathrm{CCN}$ concentrations. However, biomass burning aerosols evolve in the atmosphere, potentially altering the hygroscopic properties of the particles 
Table 1. Experimental details.

\begin{tabular}{|c|c|c|c|c|c|c|c|}
\hline $\begin{array}{c}\text { Burn } \\
\text { Number }^{\mathrm{a}}\end{array}$ & Fuel & $\begin{array}{c}\text { Primary } \\
\kappa^{\mathrm{b}}\end{array}$ & $\begin{array}{l}\text { Aged } \\
\kappa^{\mathrm{c}}\end{array}$ & $\begin{array}{l}\text { Nucleation } \\
\text { Mode } \kappa\end{array}$ & $\begin{array}{l}\text { Initial Org. Mass } \\
\text { Fraction }\end{array}$ & $\begin{array}{l}\text { OA Mass Enhancement } \\
\text { Ratio }^{\mathrm{d}}\end{array}$ & $\begin{array}{c}\text { Literature } \\
\kappa^{\mathrm{e}}\end{array}$ \\
\hline 37 & Lodgepole Pine & 0.09 & 0.09 & 0.062 & 0.94 & $1.5 \pm 0.2$ & - \\
\hline 38 & Lodgepole Pine & 0.10 & 0.11 & N/A & 0.90 & $2.3 \pm 0.7$ & - \\
\hline 40 & Ponderosa Pine & 0.10 & 0.21 & 0.223 & 0.95 & $0.9 \pm 0.1$ & 0.06 \\
\hline 42 & Wire Grass & 0.36 & 0.10 & 0.099 & 0.48 & $2.6 \pm 0.3$ & 0.19 \\
\hline 43 & Saw Grass & 0.39 & 0.17 & 0.097 & 0.35 & $2.6 \pm 0.3$ & - \\
\hline 45 & Turkey Oak & 0.22 & 0.11 & 0.106 & 0.51 & $1.8 \pm 0.3$ & 0.14 \\
\hline 47 & Galberry & 0.06 & 0.10 & 0.148 & 0.88 & $2.0 \pm 0.5$ & 0.09 \\
\hline 49 & Sage & 0.50 & 0.17 & 0.115 & 0.32 & $1.3 \pm 0.1$ & - \\
\hline 51 & Alaskan Duff & 0.07 & 0.07 & 0.097 & 0.90 & $1.2 \pm 0.1$ & 0.09 \\
\hline 53 & Sage & 0.58 & 0.27 & 0.115 & 0.35 & $1.4 \pm 0.1$ & - \\
\hline 55 & White Spruce & 0.10 & 0.12 & 0.095 & 0.76 & $1.1 \pm 0.1$ & - \\
\hline 57 & Ponderosa Pine & 0.11 & 0.14 & N/A & 0.94 & $0.9 \pm 0.1$ & 0.06 \\
\hline 59 & Chamise & 0.36 & 0.18 & N/A & 0.22 & $1.9 \pm 0.2$ & 0.33 \\
\hline 61 & Lodgepole Pine & 0.11 & 0.16 & 0.099 & 0.94 & $1.4 \pm 0.2$ & - \\
\hline 63 & Pocosin & 0.09 & 0.09 & 0.098 & 0.60 & $2.8 \pm 0.4$ & - \\
\hline 65 & Galberry & 0.08 & 0.15 & N/A & 0.90 & $0.7 \pm 0.1$ & 0.09 \\
\hline 66 & Black Spruce & 0.07 & 0.09 & 0.097 & 0.85 & $2.9 \pm 1.0$ & 0.07 \\
\hline 67 & Wire Grass & 0.29 & 0.18 & 0.109 & 0.62 & $1.4 \pm 0.1$ & 0.19 \\
\hline
\end{tabular}

a Numbering convention used during the FLAME-III study.

b Average of $0.26 \%$ and $0.43 \%$ supersaturation measurements.

c Average of $0.26 \%$ and $0.43 \%$ supersaturation measurements. Approximately last 30 min of data.

d From Hennigan et al. (2011).

e From Petters et al. (2009). Literature results reported for similar fuels where available. Experimental procedures and inversion techniques differ.

(Reid et al., 2005). The atmospheric processing of biomass burning emissions can create substantial amounts of secondary organic aerosol (SOA) (Reid et al., 2005; Yokelson et al., 2009; DeCarlo et al., 2010; Hennigan et al., 2011). In addition to the production of new organic mass via gas-toparticle conversion, the POA undergoes chemical processing that significantly alters its chemical and physical properties (Capes et al., 2008; Hennigan et al., 2010, 2011). The change in $\mathrm{CCN}$ activity as a result of atmospheric processing and condensation of SOA onto primary combustion particles remains an open question.

This work investigates the CCN activity of fresh and photochemically aged emissions from the combustion of fuels with importance for wild land fires and prescribed burns across North America.

\section{Experimental methods}

Smog chamber experiments were carried out to investigate the effects of photochemical aging on emissions from biomass fires simulated at the US Forest Service Fire Science Laboratory (FSL) in Missoula, MT as part of the Third Fire Lab at Missoula Experiment (FLAME-III) study. A total of 18 smog chamber experiments were conducted with emissions from 12 different fuels collected from different regions of North America impacted by wildfire and prescribed burning activity (Table 1). Details of the experimental setup are described by Hennigan et al. (2011). Briefly, a small fuel sample $(0.3-1 \mathrm{~kg})$ was burned in the FSL combustion chamber; after the burn was completed, emissions were transferred into a $7 \mathrm{~m}^{3}$ Teflon smog chamber via ejector diluters (Dekati, Finland) and a stainless steel transfer line heated to $40^{\circ} \mathrm{C}$. Ejector diluters added conditioned dilution air (dried, HEPAand activated-carbon filtered) creating a final dilution of approximately $25: 1$ relative to the FSL combustion chamber. Initial aerosol concentrations in the smog chamber ranged from $13-85 \mu \mathrm{g} \mathrm{m}^{-3}$. After filling, the hygroscopic properties of the primary aerosol emissions inside the chamber were characterized for $90 \mathrm{~min}$ in the dark. Photo-oxidation was then initiated by exposing the chamber to UV lights and, weather permitting, to ambient sunlight. The UV bulbs used in this study were GE model 10526 with their emitted spectrum peaking at $368 \mathrm{~nm}$. The ambient spectrum is broader than the spectrum generated from UV bulbs. The fire emissions were photochemically aged for $3-4 \mathrm{~h}$, which generated plume-relevant $\mathrm{OH}$ levels (total exposure ranging from $1.4-8.2 \times 10^{10}$ molecules $\mathrm{cm}^{-3} \mathrm{~s}$ ), to investigate the effects of photochemistry on aerosol CCN properties.

A full suite of instrumentation located in the CMU mobile air quality laboratory (Presto et al., 2011; Hennigan et al., 2011) monitored the evolution of gas- and particle-phase species inside the smog chamber. A quadrupole aerosol mass spectrometer (Q-AMS, Aerodyne) was used to monitor the chemical speciation of the non-refractory aerosol 
components. This provided the mass of organic aerosol as well the extent of oxygenation. High-volume filter samples collected in the FSL combustion chamber were analyzed for organic carbon (OC), elemental carbon (EC), and inorganic ions to provide primary aerosol chemical composition (McMeeking et al., 2009). An aethalometer (Magee Scientific model AE-31) was used to measure black carbon concentrations.

$\mathrm{CCN}$ concentrations were quantified at a range of supersaturations $(0.26-0.76 \%)$ with a continuous flow streamwise thermal gradient CCN counter (Droplet Measurement Technologies, operated at a sheath to aerosol ratio of $10: 1$ with a total flow of $0.5 \mathrm{lpm}$ ) and a condensation particle counter (CPC model 3772, TSI). Prior to analysis with the CCN counter, the particles were charged with a $\mathrm{Kr}-85$ neutralizer (TSI, 3077a) and size selected with a scanning mobility particle sizer (SMPS model 3080, TSI). Due to the fractal nature of burning emissions, aerosols were preconditioned by humidification in a warmed volumetric flask and subsequent drying with a silica gel dryer (Chakrabarty et al., 2006; Petters et al., 2009). The intention of this pre-treatment was to collapse the fractal particles into spherical particles which can be more accurately sized by the SMPS. A single activation curve was gathered in 2.25 min with a $120 \mathrm{~s}$ upscan and a $15 \mathrm{~s}$ downscan. The SMPS was operated with sheath and aerosol flows of 10 and $1.5 \mathrm{lpm}$, respectively, measuring a size range from 8 to $290 \mathrm{~nm}$.

\section{$3 \mathrm{CCN}$ analysis and theory}

\subsection{Activation diameter calculation}

Activation diameters were determined by scanning mobility CCN analysis (SMCA, Moore et al., 2010), a fast method for measuring size-resolved CCN. Briefly, a Differential Mobility Analyzer (operated in scanning voltage mode) was used to create a monodisperse aerosol population, which was then concurrently introduced into the Streamwise Thermal Gradient CCN Chamber (STGC, Roberts and Nenes, 2005) and a CPC without dilution air. The concentration time series from both instruments (CPC and STGC) is generated from instrument counts normalized by flow rate and aligned in time based upon the minimum achieved in the transition between the SMPS upscan and subsequent downscan. The comparison of these synchronized time series yields the activated particle fraction (i.e., fraction of particles that act as $\mathrm{CCN}$ ) as a function of dry mobility diameter and supersaturation. Neither the SMPS nor the CCN concentrations were corrected for multiple charge effects in the beta version of SMCA used in this analysis. The relative uncertainty from neglecting the multiple charges is approximately $3-4 \%$ in internally mixed particles (Rose et al., 2008; Moore et al., 2010). The activated fraction versus dry mobility diameter was fit to a sigmoidal curve. If the asymptote of the larger particles did not reach an activated fraction of 1 , likely due to non-activating particles, the curve was scaled to 1 prior to determination of the activation diameter. The activation diameter was calculated as the diameter corresponding to the $50 \%$ point on the sigmoid.

The $\mathrm{CCN}$ counter supersaturation was calibrated using size-classified ammonium sulfate aerosol following the procedure of Rose et al. (2008) and Engelhart et al. (2008). Köhler calculations for the effective supersaturation assumed the surface tension and density of water and a temperature equal to the average of the top and bottom temperatures of the column in the CCNC. The van't Hoff factor was determined from a Pitzer model as a function of diameter. Full calibrations (supersaturations between 0.1 and $1.5 \%$ ) conducted before, in the middle, and after the last experiment were indistinguishable. Daily checks on the calibration were conducted at the supersaturations of interest (typically 0.26 , 0.43 , and $0.76 \%$ supersaturation).

\subsection{Hygroscopicity theory}

Petters and Kreidenweis (2007) proposed a hygroscopicity parameterization, $\kappa$, derived from Köhler theory, to describe the observed $\mathrm{CCN}$ activity of aerosol:

$S(D)=\frac{D^{3}-D_{\mathrm{d}}^{3}}{D^{3}-D_{\mathrm{d}}^{3}(1-\kappa)} \exp \left(\frac{4 \sigma_{\mathrm{s} / \mathrm{a}} M_{\mathrm{w}}}{R T \rho_{\mathrm{w}} D}\right)$,

where $D$ is the diameter of the droplet, $D_{\mathrm{d}}$ is the diameter of the dry solute, $S$ is the supersaturation, $\sigma_{\mathrm{s} / \mathrm{a}}$ is the surface tension of the solution/air interface, $M_{\mathrm{w}}$ is the molecular weight of water, $R$ is the universal gas constant, $\rho_{\mathrm{w}}$ is the density of water, and $T$ is temperature.

For submicron CCN with a substantial soluble fraction, $\kappa$ can be determined from knowledge of the critical supersaturation and activation diameter of particles as,

$\kappa=\frac{4 A^{3}}{27 D_{\mathrm{d}}^{3} \ln ^{2} S_{c}}$

where $A=\frac{4 M_{\mathrm{w}} \sigma_{\mathrm{S}} / \mathrm{a}}{R T \rho_{\mathrm{w}}}$, and $\sigma_{\mathrm{s} / \mathrm{a}}$ is the surface tension of the solution/air interface $\left(\sigma_{\mathrm{s} / \mathrm{a}}=0.072 \mathrm{~J} \mathrm{~m}^{-2}\right.$ and $\left.T=298 \mathrm{~K}\right)$.

For multicomponent systems the overall kappa is defined by a simple mixing rule:

$\kappa=\sum_{i} \varepsilon_{i} \kappa_{i}$

where $\varepsilon_{i}$ is the volume fraction of the individual component, $i$, and $\kappa_{i}$ is the hygroscopicity parameter for the individual component.

\section{Results and discussion}

Figure 1 shows a representative time series of particle mass (estimated from SMPS volume concentration assuming 


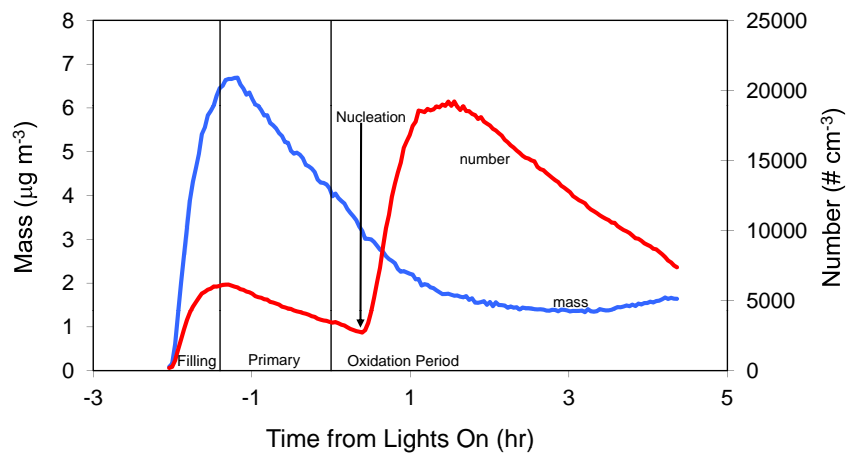

Fig. 1. Measured aerosol mass and number concentration versus time for a typical experiment (Turkey Oak, burn 45). The results have not been corrected for losses to the walls. The particle number increases during a strong nucleation event in all experiments shortly after lights on.

spherical particles and a density of $1 \mathrm{~g} \mathrm{~cm}^{-3}$ ) and number concentrations from the experiment conducted with Turkey Oak emissions (burn 45). The particle mass and number concentrations increased rapidly as the smog chamber was filled with exhaust from the burn chamber. After filling, the smog chamber was sealed and the primary aerosol number and mass concentrations decreased due to deposition to the chamber walls. The organic component of this initial, fresh aerosol is considered POA for the purposes of this study. The primary emissions have both a carbonaceous component (POA and elemental carbon) and an inorganic component. After about a 90 min period to characterize the fresh aerosol, the chamber was exposed to ultra-violet light (time 0 ), which dramatically increased particle number due to new particle formation induced by photochemical processes. This phenomenon was observed in essentially every FLAME-III aging experiment (Hennigan et al., 2012). During the photo-oxidation period the suspended mass increased slightly due to production of secondary organic aerosol (SOA), despite the loss of particles to the walls. The SOA production was quantified by changes in the organic aerosol-to-black-carbon ratio (Hennigan et al., 2011); the OA mass enhancement ratio from Hennigan et al. (2011) for each experiment is listed in Table 1. A ratio of 1 indicates that photo-oxidation produced no new aerosol mass; a ratio of two indicates that SOA production doubled the OA mass; a ratio below 1 indicates evaporation of organic material. Overall, photo-oxidation resulted in highly variable SOA production across the entire set of experiments (Hennigan et al., 2011).

\subsection{CCN activity of fresh biomass burning particles}

Initial CCN hygroscopicities of the primary aerosol were measured after filling but before the chamber was exposed to UV lights. $\kappa$ values of the primary aerosol ranged from 0.06 to 0.6 as shown in blue bars in Fig. 2 for 0.26 and $0.43 \%$ supersaturations. These data are also presented in Table 1 .
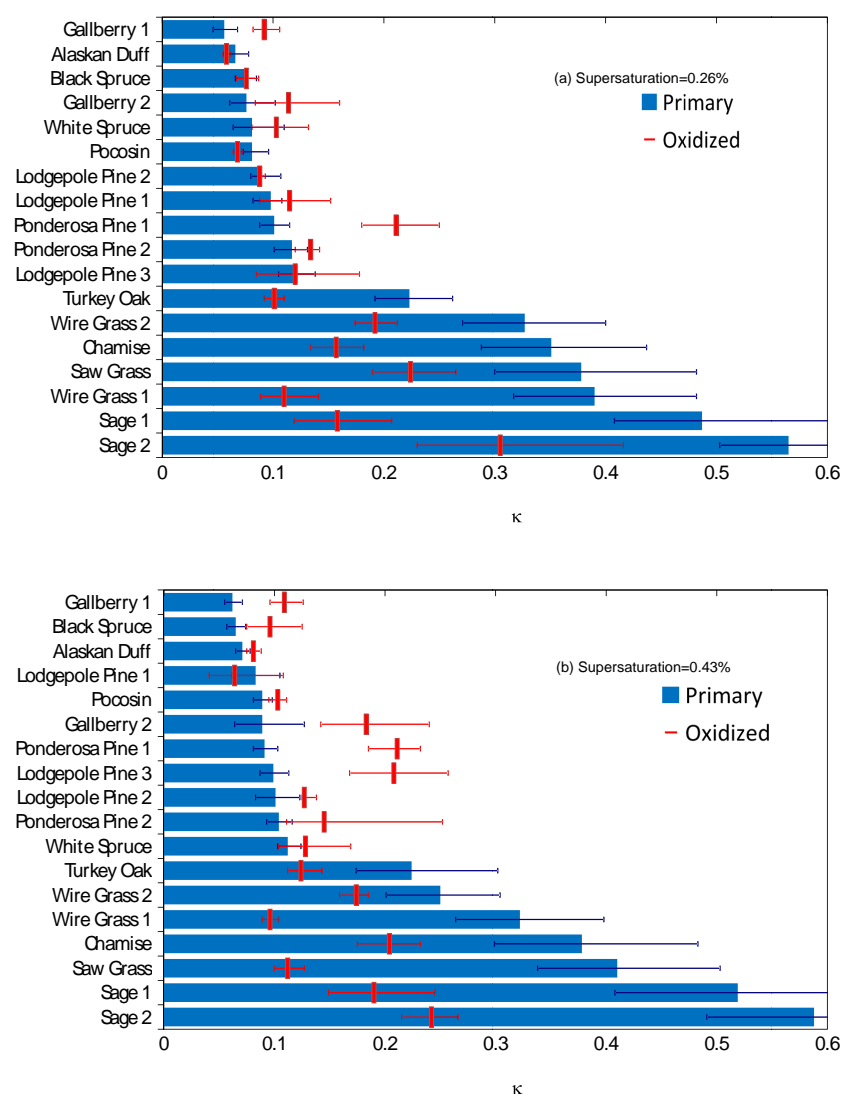

Fig. 2. Kappa values for each fuel given for primary aerosol (blue bars) and aged (average of final $30 \mathrm{~min}$ ) aerosol containing both primary and secondary organic aerosol (red bars) (a) $\mathrm{SS}=0.26 \%$ (b) $\mathrm{SS}=0.43 \%$. Blue and red error bars indicate one standard deviation in activation diameter reflected in kappa values for primary and aged aerosols, respectively.

For most experiments, the $\kappa$ values measured at 0.26 and $0.43 \%$ supersaturation were quite similar, indicating a homogeneous chemical composition with size. For example, a linear regression of 18 paired sets of $\kappa$ values measured at 0.26 and $0.43 \%$ yields a slope $=1.01$, intercept $=0.003$, and $R^{2}=0.97$. In a few experiments, there were differences in $\kappa$ values measured at different supersaturations. For example, in the second experiment conducted with wire grass emissions (burn 67), the measured $\kappa$ values were 0.33 and 0.25 at $0.26 \%$ and $0.43 \%$ supersaturation, respectively. This may indicate variable aerosol chemical composition as a function of size as the higher activity at lower supersaturations may be due to a higher concentration of inorganics at larger particle sizes. We could not explain the variation in kappa by variations in the dilution. The variation in kappa was not consistently higher at one supersaturation something that would be expected if evaporation in the $\mathrm{CCN}$ counter was causing an experimental bias. We measured the volatility of the particles with a thermodenuder and their evaporation at the $\mathrm{CCN}$ counter conditions was negligible. 


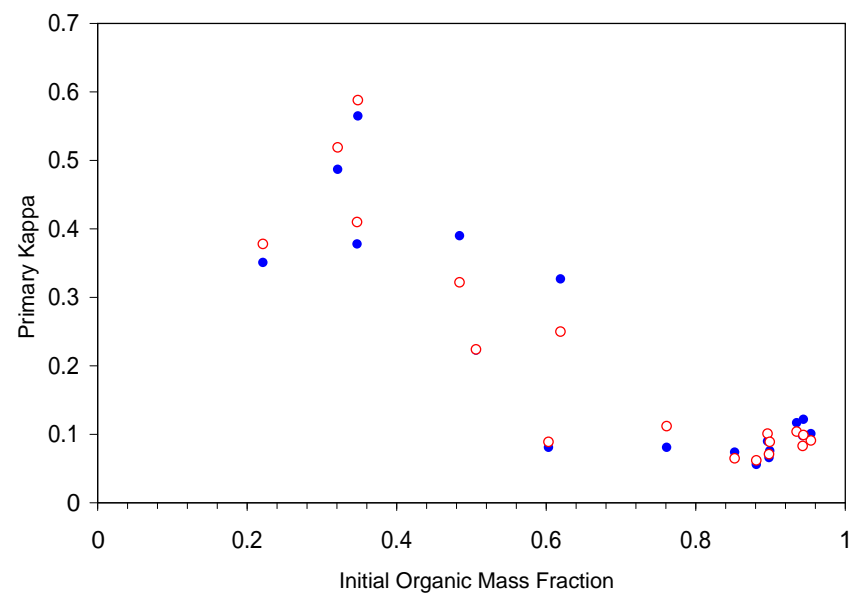

Fig. 3. Kappa of the primary aerosol versus organic mass fraction. Data for $0.26 \%$ supersaturation are shown in blue and for $0.43 \%$ supersaturation are shown in red.

The grasses (saw grass and wire grass) as well as sage had the highest primary $\kappa$ values whereas the evergreens (Ponderosa Pine, Lodgepole Pine, White Spruce, Black Spruce) had the lowest. This trend is consistent with CCN data for similar fuels measured during FLAME-II, where the primary aerosol CCN activity ranged from a $\kappa$ value of 0.06 for Ponderosa Pine to a $\kappa$ value of 0.7 for Saw Grass (Petters et al., 2009).

The variation in initial $\mathrm{CCN}$ activity was largely due to the inorganic component of the primary aerosol. The aerosol organic mass fraction was calculated as the ratio of the Q-AMS organic mass to the sum of the total Q-AMS non-refractory aerosol mass plus black carbon. This value agreed well with data from high volume filter measurements collected to characterize the primary aerosol in the FSL combustion chamber. Figure 3 plots the primary aerosol $\kappa$ as a function of the organic mass fraction. There is a clear relationship between these two parameters: as the organic mass fraction increases, the $\kappa$ value of the primary aerosol decreases, consistent with the results of Petters et al. (2009). This is qualitatively due to the mixing rule (Eq. 3) and the fact that inorganic compounds have significantly higher $\kappa$ values than organics (Petters and Kreidenweis, 2007). More complete inorganic sizing information is required to test the mixing rule quantitatively.

Although the inorganic fraction appears to be the most important factor in primary aerosol hygroscopicity, there is also a relationship between the primary aerosol kappa and the extent of oxygenation of the POA. Figure 4 shows a trend of increasing $\kappa$ for the total primary aerosol (inorganics + organic aerosol + elemental carbon) with increasing $f_{44}$ measured in the Q-AMS. $f_{44}$ is the fractional contribution of the mass-to-charge $(m / z) 44$ ion (primarily the $\mathrm{CO}_{2}^{+}$ion) to the total organic concentration measured in the AMS. It is related to the $\mathrm{O}: \mathrm{C}$ ratio of the organic aerosol (Aiken et al., 2008). However, the inorganic fraction of the particles was

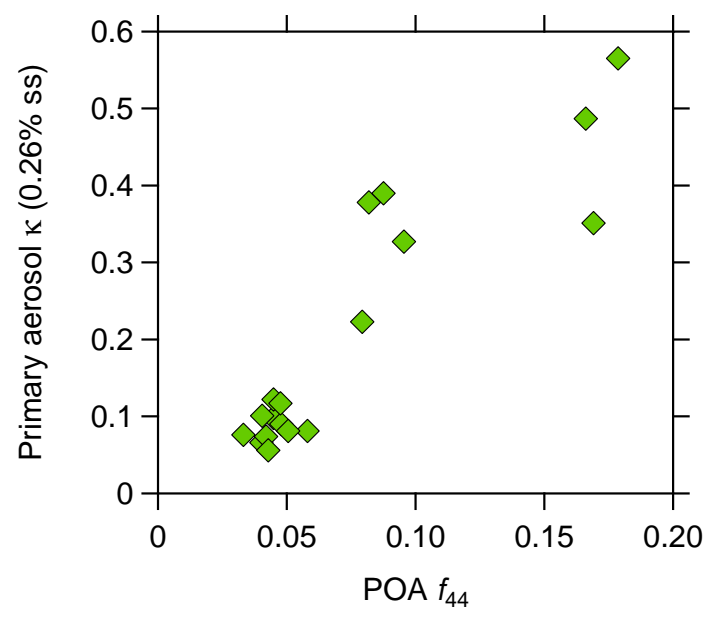

Fig. 4. Primary aerosol kappa vs. $f_{44}$ measured in the POA. $f_{44}$ is the ratio of the mass-to-charge $(\mathrm{m} / \mathrm{z}) 44$ ion to the total organic signal measured with the Q-AMS.

also increasing as the $f_{44}$ was increasing making the separation of the two effects (inorganic content and hygroscopicity of the POA) on the total hygroscopicity of the particles difficult. Laboratory (Engelhart et al., 2008; Massoli et al., 2010) and field (Chang et al., 2010) studies that have observed an increase in the hygroscopicity of organic aerosol as it becomes more oxidized. However, other laboratory work has not found a trend linking $\kappa$ to oxygen to carbon molar ratio or to $f_{44}$ (Frosch et al., 2011).

\subsection{CCN activity of aged biomass burning particles}

After the primary characterization period, the chamber was exposed to UV light to initiate photo-chemistry. Aerosol, trace gas, and oxidant concentrations inside the chamber were comparable to conditions inside dilute biomass burning plumes, suggesting that the timescale for transformation in our experiments are comparable to those in ambient plumes (Hennigan et al., 2011).

Time series of measured activation diameter from two experiments are plotted in Fig. 5 to illustrate common responses of the CCN activity of biomass burning aerosol to photooxidation. In the sage experiment, photo-oxidation dramatically increased the activation diameter, indicating the aged aerosol became less CCN active. In the ponderosa pine experiment, photo-oxidation decreased the activation diameter, indicating that the aging made the aerosol more $\mathrm{CCN}$ active.

Figure 2 depicts the change in $\kappa$ due to photo-oxidation for all fuels at both $0.26 \%$ and $0.43 \%$ supersaturations. The red lines in Fig. 2 correspond to the average $\kappa$ measured at the end of the photo-oxidation period; these data are also provided in Table 1. The trends shown in Fig. 5 were observed consistently across the set of experiments. In experiments with high $\mathrm{CCN}$ active primary aerosol, photo-oxidation reduced the $\mathrm{CCN}$ activity of the emissions. In experiments with 


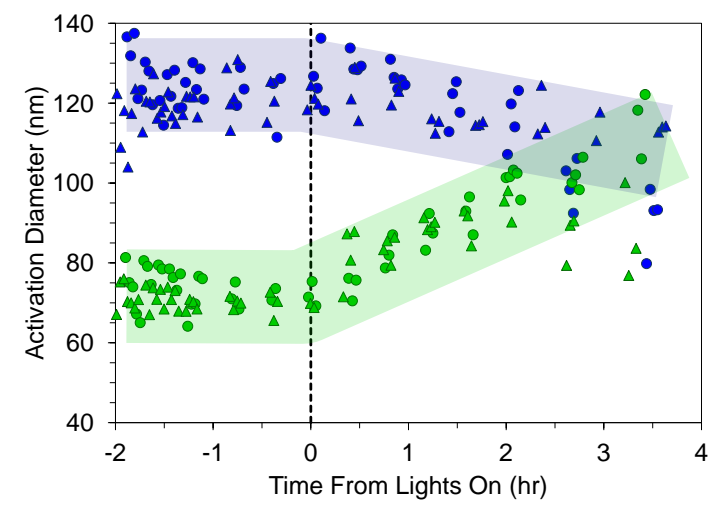

Fig. 5. CCN activation diameter versus time from lights on for Ponderosa Pine (blue) and Sage (green) experiments at $0.26 \%$ supersaturation. Trends for other supersaturations are similar. Circles and triangles denote replicate experiments. The shaded regions are provided to guide the eye.

initially less CCN active particles, photo-oxidation increased the CCN activity of the aerosol.

Figure 6 shows histograms of $\kappa$ values for the primary aerosol (Fig. 6a) and the aged aerosol (Fig. 6b) for all of the fuels investigated. For reference, pure ammonium sulfate particles ( $\kappa=0.61$, Petters and Kreidenweis, 2007) would be in the far right-hand bin and laboratory SOA $(\kappa \approx$ 0.1 , Prenni et al., 2007) would be in the first or second bins in Fig. 6. The narrower distribution of $\kappa$ for the aged aerosol (Fig. 6b) demonstrates that photo-chemical processing causes the CCN activity of the biomass burning aerosol to converge to values typical of laboratory generated SOA (Prenni et al., 2007).

The convergence of $\kappa$ with photo-chemical aging in our chamber experiments is consistent with ambient measurements of CCN activity in biomass burning plumes where kappa values show much less variability than the primary emissions (Petters et al., 2009). One study of ambient aerosols in China near an area of active biomass burning found that using a campaign average $\kappa$ value (0.3) and measured size distributions predicted $\mathrm{CCN}$ number concentrations on average within $20 \%$ of measurements (Rose et al., 2010). This was despite the measured $\kappa$ value range of $0.1-$ 0.5 . Additionally, ambient measurements of aerosol plumes transported to Alaska showed a low variance in $\kappa$ value $(0.1-$ $0.3)$ despite chemical compositions ranging from biomass burning plumes to pristine sea ice boundary layer air (Moore et al., 2011).

There are several factors which contributed to the convergence of $\kappa$ with photo-chemical aging. Since the $\kappa$ of a multicomponent aerosol system is a weighted average of the $\kappa$ values of the individual components (Eq. 3), the production of SOA mass can result in significant changes to the overall aerosol $\kappa$. In addition, SOA production and new particle formation caused by photo-oxidation can dramatically change the aerosol size distribution.
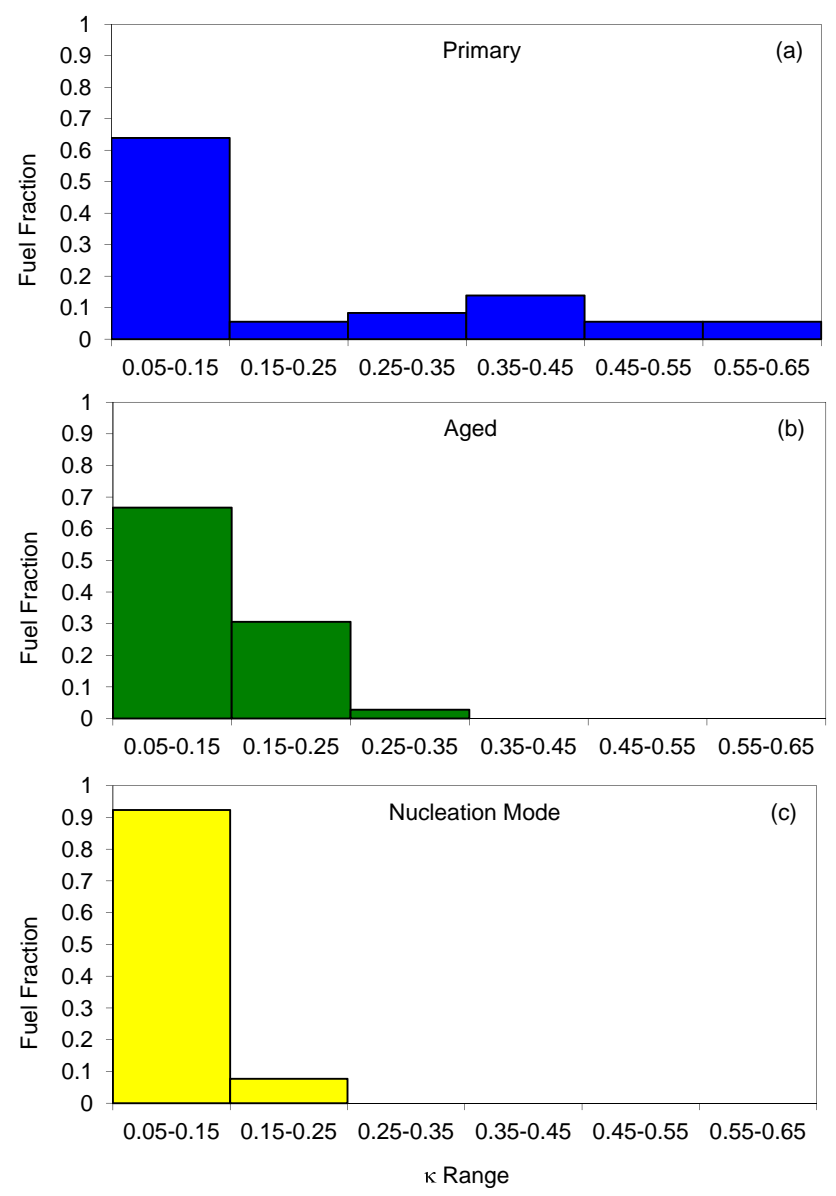

Fig. 6. Histogram of measured kappa values: (a) fresh emissions; (b) aged emissions; and (c) nucleation mode aerosol (SOA). Data for 0.26 and $0.43 \%$ supersaturation are shown for primary and aged distributions. For the nucleation mode data for $0.76 \%$ supersaturation is shown.

The most significant changes to $\kappa$ were observed in experiments with high initial inorganic mass fractions (Fig. 7). The production of SOA can dramatically reduce $\kappa$ values in these systems since the $\kappa$ of organics is generally far lower than that of inorganics (Petters and Kreidenweis, 2007). In some experiments with large reductions in $\kappa$, the data cannot be explained solely by changes in aerosol composition. For example, in the first experiment with sage emissions (burn 49), photo-chemical aging caused a reduction in $\kappa$ from 0.49 to 0.16 but SOA formation only increased the total organic aerosol mass by $30 \%$ (i.e., an OA mass enhancement ratio of 1.3, Table 1). This suggests that some of the reduction in $\kappa$ may have been caused by changes in the aerosol size distribution. Essentially, SOA formation increases the particle size, growing some of the inorganic material outside of the size region of the CCN activation measurements $(290 \mathrm{~nm}$ upper size limit). The $\kappa$ value of the aged aerosol distribution $(10-290 \mathrm{~nm})$ was also heavily impacted by new particle formation, since the growth of these new particles was driven 


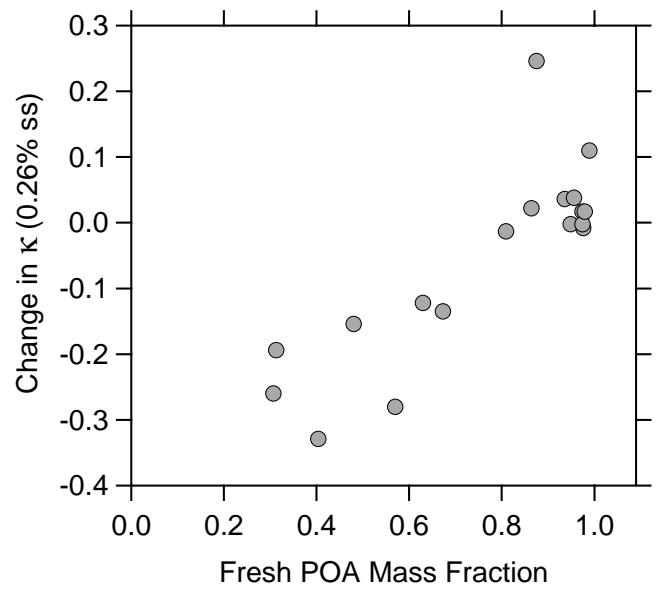

Fig. 7. Change in $\kappa$ value after $3.5-4.5 \mathrm{~h}$ of photochemical aging vs. the organic mass fraction of the primary aerosol.

almost entirely by SOA formation (Hennigan et al., 2012). Thus the combination of SOA condensation onto the nucleated particles and the growth of some primary particles out of the size range relevant for $\mathrm{CCN}$ activation likely contributed to the significant decrease in $\kappa$ for fuels with high primary inorganic aerosol content. Conversely, while the changes were more subtle for fuels with high organic content in the primary aerosol, the difference between the $\kappa$ of the photo-chemically generated organic aerosol and the POA drove a change in the $\mathrm{CCN}$ activity. The more oxidized SOA typically led to an increase in $\mathrm{CCN}$ activity for the heavily organic primary aerosols.

Photo-oxidation induced significant new particle formation in essentially every experiment (except for burn 59, Chamise). The nucleated particles often grew and became $\mathrm{CCN}$ active at the higher supersaturations $(0.43 \%$ and $0.76 \%$ ) by the end of the photo-oxidation period. Since this growth was dominated by SOA formation, CCN measurements on the nucleation mode provide estimates of the hygroscopic properties of SOA from biomass burning emissions. The nucleation mode SOA $\kappa$ was not determined in 4 experiments for three reasons: lack of measurement information at the higher supersaturations, lack of growth into the measurable size window, or insufficient particle concentration late in the experiment to determine the activation diameter. Figure $6 \mathrm{c}$ presents a histogram of $\kappa$ values determined from analysis of the nucleation mode in 14 experiments (Table 1). Excluding the ponderosa pine experiment (burn 40), the average biomass burning SOA $\kappa$ was $0.10 \pm 0.02$ (mean $\pm \sigma)$. This is similar to $\kappa$ values observed for monoterpene SOA generated in laboratory experiments (Engelhart et al., 2008, 2011; King et al., 2010). The $\kappa$ for the ponderosa pine (burn 40) SOA was much higher than that measured in any other experiment. To our knowledge, this represents the first direct quantification of $\kappa$ values for biomass burning SOA. The similarity in $\kappa$ values observed for SOA generated from a diverse array of fuels suggests that the average $\kappa$ for biomass burning SOA from our study (approximately 0.1) can be applied for modeling applications.

In experiments where the primary aerosol had a high initial organic mass fraction $(>80 \%)$, the behavior of the primary aerosol is dominated by the organic aerosol (POA) content. The addition of SOA mass did not produce significant changes to $\kappa$ in these experiments suggesting that the hygroscopicity of the POA and SOA were similar (Figs. 2 and 7). For example, in the experiment with black spruce (burn 66), where the initial organic aerosol mass fraction was $85 \%$, the production of SOA nearly tripled the organic aerosol mass but the primary and aged $\kappa$ values were 0.07 and 0.09 (Table 1), respectively. The $\kappa$ of the black spruce SOA was 0.097 , which led to the modest increase in $\kappa$ for the photochemically aged aerosol. The average $\kappa$ of primary aerosol for fuels with high initial organic mass fraction $(>80 \%)$ was $0.089(n=11)$, which is close to the $\kappa$ value of 0.103 determined for the SOA from the analysis of the nucleation mode.

\section{Conclusions}

In this study, we have quantified the hygroscopicity of primary and photo-chemically aged aerosol from biomass burning emissions. The $\kappa$ values of primary aerosol were highly variable, ranging between 0.06 (weakly hygroscopic) and 0.6 (highly hygroscopic). The hygroscopicity of the primary aerosol was inversely related to the organic fraction of the particles demonstrating the importance of inorganic components on the primary aerosol hygroscopicity.

Photochemical processing reduced the variability in $\kappa$, causing it to converge to $0.1-0.2$. The change in $\kappa$ was most pronounced for systems that had high inorganic aerosol mass fractions, demonstrating the importance of SOA in altering the chemical and physical properties of aerosols in the atmosphere. For aerosol with high initial organic mass fractions, the change in $\kappa$ with photochemical aging was small, indicating similar $\kappa$ values for the SOA and POA in these systems. This was confirmed by separate quantification of the hygroscopicity of particles generated in situ during the experiments due to photo-chemical processes. These new particles nucleated and grew due to the condensation of SOA, and thus, we directly quantified $\kappa$ for biomass burning SOA. The $\kappa$ for biomass burning SOA was highly consistent across our experiments, and had an average $\kappa$ value of approximately 0.1 .

Overall, these results indicate that the otherwise diverse $\mathrm{CCN}$ properties of biomass burning may converge to a more similar activity after a few hours of photo-oxidation at atmospherically relevant conditions. This is significant for modelling studies as this is an indication that the otherwise very diverse $\mathrm{CCN}$ properties of biomass burning may converge to a more similar activity with atmospheric processing on short time scales. 
Acknowledgements. Funding for the FLAME III study was provided by the National Park Service and Joint Fire Science Program and the EPA STAR program through the National Center for Environmental Research (NCER) under grant R833747. SNP acknowledges the support of the FP7 IDEAS project ATMOPACS. We thank the staff at FSL and especially Cyle Wold, Emily Lincoln, and Wei Min Hao for support for this project, Jeffrey Collett and Sonia M. Kreidenweis for organizing the campaign and Amy Sullivan for supporting measurements. This paper has not been subject to the EPA's required peer and policy review, and therefore does not necessarily reflect the views of the Agency. No official endorsement should be inferred.

Edited by: M. Gysel

\section{References}

Aiken, A. C., DeCarlo, P. F., Kroll, J. H., Worsnop, D. R., Huffman, J. A., Docherty, K. S., Ulbrich, I. M., Mohr, C., Kimmel, J. R., Sueper, D., Sun, Y., Zhang, Q., Trimborn, A., Northway, M., Ziemann, P. J., Canagaratna, M. R., Onasch, T. B., Alfarra, M. R., Prevot, A. S. H., Dommen, J., Duplissy, J., Metzger, A., Baltensperger, U., and Jimenez, J. L.: O/C and OM/OC ratios of primary, secondary, and ambient organic aerosols with high resolution time-of-flight aerosol mass spectrometry, Environ. Sci. Technol., 42, 4478-4485, doi:10.1021/es703009q, 2008.

Andreae, M. O., Rosenfeld, D., Artaxo, P., Costa, A. A., Frank, G. P., Longo, K. M., and Silva-Dias, M. A. F.: Smoking rain clouds over the Amazon, Science, 303, 1337-1342, doi:10.1126/science.1092779, 2004.

Capes, G., Johnson, B., McFiggans, G., Williams, P. I., Haywood, J., and Coe, H.: Aging of biomass burning aerosols over West Africa: Aircraft measurements of chemical composition, microphysical properties, and emission rates, J. Geophys. Res., 113, D00C15, doi:10.1029/2008JD009845, 2008.

Chakrabarty, R. K., Moosmüller, H., Garro, M. A., Arnott, W. P., Walker, J., Susott, R. A., Babbitt, R. E., Wold, C. E., Lincoln, E. N., and Hao, W. M.: Emissions from the laboratory combustion of wildland fuels: Particle morphology and size, J. Geophys. Res., 111, D07204, doi:07210.01029/02005JD006659, 2006.

Chang, R. Y.-W., Slowik, J. G., Shantz, N. C., Vlasenko, A., Liggio, J., Sjostedt, S. J., Leaitch, W. R., and Abbatt, J. P. D.: The hygroscopicity parameter $(\kappa)$ of ambient organic aerosol at a field site subject to biogenic and anthropogenic influences: relationship to degree of aerosol oxidation, Atmos. Chem. Phys., 10, 5047-5064, doi:10.5194/acp-10-5047-2010, 2010.

Crutzen, P. J. and Andreae, M. O.: Biomass burning in the tropics: Impact on atmospheric chemistry and biogeochemical cycles, Science, 250, 1669-1678, doi:10.1126/science.250.4988.1669, 1990.

DeCarlo, P. F., Ulbrich, I. M., Crounse, J., de Foy, B., Dunlea, E. J., Aiken, A. C., Knapp, D., Weinheimer, A. J., Campos, T., Wennberg, P. O., and Jimenez, J. L.: Investigation of the sources and processing of organic aerosol over the Central Mexican Plateau from aircraft measurements during MILAGRO, Atmos. Chem. Phys., 10, 5257-5280, doi:10.5194/acp-10-52572010, 2010.

Eagan, R. C., Hobbs, P. V., and Radke, L. F.: Measurements of cloud condensation nuclei and cloud droplet size distributions in the vicinity of forest fires, J. Appl. Meteor., 13, 553-557, 1974.

Engelhart, G. J., Asa-Awuku, A., Nenes, A., and Pandis, S. N.: CCN activity and droplet growth kinetics of fresh and aged monoterpene secondary organic aerosol, Atmos. Chem. Phys., 8, 39373949, doi:10.5194/acp-8-3937-2008, 2008.

Engelhart, G. J., Moore, R. H., Nenes, A., and Pandis, S. N.: Cloud condensation nuclei activity of isoprene secondary organic aerosol, J. Geophys. Res., 116, D02207, doi:10.1029/2010JD014706, 2011.

Frosch, M., Bilde, M., DeCarlo, P., Jurányi, Z., Tritscher, T., Dommen, J., Donahue, N. M., Gysel, M., Weingartner, E., and Baltensperger, U.: Relating CCN activity and oxidation level of $\alpha$-pinene secondary organic aerosol, J. Geophys. Res., 116, D22212, doi:10.1029/2011JD016401, 2011.

Hennigan, C. J., Sullivan, A. P., Collett Jr., J. L., and Robinson, A. L.: Levoglucosan stability in biomass burning particles exposed to hydroxyl radicals, Geophys. Res. Lett., 37, L09806, doi:10.1029/2010GL043088, 2010.

Hennigan, C. J., Miracolo, M. A., Engelhart, G. J., May, A. A., Presto, A. A., Lee, T., Sullivan, A. P., McMeeking, G. R., Coe, H., Wold, C. E., Hao, W.-M., Gilman, J. B., Kuster, W. C., de Gouw, J., Schichtel, B. A., J. L. Collett Jr., Kreidenweis, S. M., and Robinson, A. L.: Chemical and physical transformations of organic aerosol from the photo-oxidation of open biomass burning emissions in an environmental chamber, Atmos. Chem. Phys., 11, 7669-7686, doi:10.5194/acp-11-7669-2011, 2011.

Hennigan, C. J., Westervelt, D. M., Riipinen, I., Engelhart, G. J., Lee, T., Collett Jr., J. L., Pandis, S. N., Adams, P. J., and Robinson, A. L.: New particle formation and growth in biomass burning plumes: An important source of cloud condensation nuclei, Geophys. Res. Lett., 39, L09805, doi:10.1029/2012GL050930, 2012.

Hobbs, P. V. and Radke, L. F.: Cloud condensation nuclei from a simulated forest fire, Science, 163, 279-280, 1969.

King, S. M., Rosenoern, T., Shilling, J. E., Chen, Q., Wang, Z., Biskos, G., McKinney, K. A., Pöschl, U., and Martin, S. T.: Cloud droplet activation of mixed organic-sulfate particles produced by the photooxidation of isoprene, Atmos. Chem. Phys., 10, 3953-3964, doi:10.5194/acp-10-3953-2010, 2010.

Massoli, P., Lambe, A. T., Ahern, A. T., Williams, L. R., Ehn, M., Mikkilä, J., Canagaratna, M. R., Brune, W. H., Onasch, T. B., Jayne, J. T., Petäjä, T., Kulmala, M., Laaksonen, A., Kolb, C. E., Davidovits, P., and Worsnop, D. R.: Relationship between aerosol oxidation level and hygroscopic properties of laboratory generated secondary organic aerosol (SOA) particles. Geophys. Res. Lett., 37, L24801, doi:10.1029/2010GL045258, 2010.

McMeeking, G. R., Kreidenweis, S. M., Baker, S., Carrico, C. M., Chow, J. C., Collett Jr., J. L., Hao, W. M., Holden, A. S., Kirschstetter, T. W., Malm, W. M., Moosmuller, H., Sullivan, A. P., and Wold, C. E.: Emissions of trace gases and aerosols during the open combustion of biomass in the laboratory, J. Geophys. Res., 114, D19210, doi:10.1029/2009JD011836, 2009.

Moore, R. H., Nenes, A., and Medina, J.: Scanning Mobility CCN Analysis - A method for fast measurements of size-resolved CCN distributions and activation kinetics, Aerosol Sci. Technol., 44, 861-871, doi:10.1080/02786826.2010.498715, 2010.

Moore, R. H., Bahreini, R., Brock, C. A., Froyd, K. D., Cozic, J., Holloway, J. S., Middlebrook, A. M., Murphy, D. M., and Nenes, A.: Hygroscopicity and composition of Alaskan Arctic 
CCN during April 2008, Atmos. Chem. Phys., 11, 11807-11825, doi:10.5194/acp-11-11807-2011, 2011.

Novakov, T. and Corrigan, C. E.: Cloud condensation nucleus activity of the organic component of biomass smoke particles, Geophys. Res. Lett., 23, 2141-2144, 1996.

Petters, M. D. and Kreidenweis, S. M.: A single parameter representation of hygroscopic growth and cloud condensation nucleus activity, Atmos. Chem. Phys., 7, 1961-1971, doi:10.5194/acp-71961-2007, 2007.

Petters, M. D., Prenni, A. J., Kreidenweis, S. M., and DeMott, P. J.: On measuring the critical diameter of cloud condensation nuclei using mobility selected aerosol, Aerosol Sci. Technol., 41, 907913, doi:10.1080/02786820701557214, 2007.

Petters, M. D., Carrico, C. M., Kreidenweis, S. M., Prenni, A. J., DeMott, P. J., Collett, J. L., and Moosmuler, H.: Cloud condensation nucleation activity of biomass burning aerosol, J. Geophys. Res., 114, D22205, doi:10.1029/2009JD012353, 2009.

Pierce, J. R., Chen, K., and Adams, P. J.: Contribution of primary carbonaceous aerosol to cloud condensation nuclei: processes and uncertainties evaluated with a global aerosol microphysics model, Atmos. Chem. Phys., 7, 5447-5466, doi:10.5194/acp-75447-2007, 2007.

Prenni, A. J., Petters, M. D., Kreidenweis, S. M., DeMott, P. J., and Ziemann, P. J.: Cloud droplet activation of secondary organic aerosol, J. Geophys. Res., 112, D10223, doi:10.1029/2006JD007963, 2007.

Presto, A. A., Nguyen, N. T., Ranjan, M., Reeder, A. J., Lipsky, E. M., Hennigan, C. J., Miracolo, M. A., Riemer, D. D., and Robinson, A. L.: Fine particle and organic vapor emissions from staged tests of an in-use aircraft engine, Atmos. Environ., 45, 3603-3612, 2011.

Reid, J. S., Koppmann, R., Eck, T. F., and Eleuterio, D. P.: A review of biomass burning emissions part II: intensive physical properties of biomass burning particles, Atmos. Chem. Phys., 5, 799825, doi:10.5194/acp-5-799-2005, 2005.

Reutter, P., Su, H., Trentmann, J., Simmel, M., Rose, D., Gunthe, S. S., Wernli, H., Andreae, M. O., and Pöschl, U.: Aerosol- and updraft-limited regimes of cloud droplet formation: influence of particle number, size and hygroscopicity on the activation of cloud condensation nuclei (CCN), Atmos. Chem. Phys., 9, 70677080, doi:10.5194/acp-9-7067-2009, 2009.
Roberts, G. C. and Nenes, A.: A continuous-flow streamwise thermal-gradient $\mathrm{CCN}$ chamber for atmospheric measurements, Aerosol Sci. Technol., 39, 206-221, doi:10.1080/027868290913988, 2005.

Rogers, C. F., Hidson, J. G., Zeilinska, B., Tanner, R. L., Hallett, J., and Watson, J. G.: Cloud condensation nuclei from biomass burning, in: Global Biomass Burning: Atmospheric, Climatic, and Biospheric Implications, edited by: Levine, J. S., MIT Press, Cambridge, MA, 431-440, 1991.

Rose, D., Gunthe, S. S., Mikhailov, E., Frank, G. P., Dusek, U., Andreae, M. O., and Pöschl, U.: Calibration and measurement uncertainties of a continuous-flow cloud condensation nuclei counter (DMT-CCNC): CCN activation of ammonium sulfate and sodium chloride aerosol particles in theory and experiment, Atmos. Chem. Phys., 8, 1153-1179, doi:10.5194/acp-8-11532008, 2008.

Rose, D., Nowak, A., Achtert, P., Wiedensohler, A., Hu, M., Shao, M., Zhang, Y., Andreae, M. O., and Pöschl, U.: Cloud condensation nuclei in polluted air and biomass burning smoke near the mega-city Guangzhou, China - Part 1: Size-resolved measurements and implications for the modeling of aerosol particle hygroscopicity and CCN activity, Atmos. Chem. Phys., 10, 33653383, doi:10.5194/acp-10-3365-2010, 2010.

Spracklen, D. V., Carslaw, K. S., Pöschl, U., Rap, A., and Forster, P. M.: Global cloud condensation nuclei influenced by carbonaceous combustion aerosol, Atmos. Chem. Phys., 11, 9067-9087, doi:10.5194/acp-11-9067-2011, 2011.

Warner, J. and Twomey, S.: The production of cloud nuclei by cane fires and the effect on cloud drop concentrations, J. Atmos. Sci., 24, 704-713, 1967.

Yokelson, R. J., Crounse, J. D., DeCarlo, P. F., Karl, T., Urbanski, S., Atlas, E., Campos, T., Shinozuka, Y., Kapustin, V., Clarke, A. D., Weinheimer, A., Knapp, D. J., Montzka, D. D., Holloway, J., Weibring, P., Flocke, F., Zheng, W., Toohey, D., Wennberg, P. O., Wiedinmyer, C., Mauldin, L., Fried, A., Richter, D., Walega, J., Jimenez, J. L., Adachi, K., Buseck, P. R., Hall, S. R., and Shetter, R.: Emissions from biomass burning in the Yucatan, Atmos. Chem. Phys., 9, 5785-5812, doi:10.5194/acp-9-5785-2009, 2009. 